Syntax Literate : Jurnal Ilmiah Indonesia p-ISSN: 2541-0849

e-ISSN: 2548-1398

Vol. 5, No. 6, Juni 2020

\title{
CLAIM LOSS RATIO RATE SEBAGAI INDIKATOR PENGAMBILAN KEPUTUSAN PERUBAHAN HARGA PREMI ASURANSI JIWA
}

\author{
Mardianto Karim dan Aceng Komarudin Mutaqin \\ Program Studi Statistika Universitas Islam Bandung \\ Email: mardianto.karim.mk@gmail.com dan aceng.k.mutaqin@gmail.com
}

\begin{abstract}
The insurance world is inseparable from the name premium. Every insurance product sold by an insurance company must have a premium price that always follows it. The insurance company must ascertain whether the pre-determined premium on a product can still be used at a subsequent sale in order to meet obligations for claims made by customers. To establish the right premium for consumers, insurance companies can conduct experience studies based on past information. In this study, an experience study was applied to the risk of life insurance product $X$ claims sold by life insurance company $Y$. By using the experience study will be generated a claim loss ratio rate to find out how the comparison of the actual state of the claim against the risk expected by insurance companies in the form of premiums can help insurance companies in making decisions on changes in premium prices. The final results of this study produce the conclusion that the claim loss ratio rate for product $X$ for both male and female customers is below 100\% and below the general limit (40-50\%) so that the premiums determined are still sufficient to pay the claims submitted and insurance companies may consider decreasing the price of premium for product $X$.
\end{abstract}

Keywords: Experience study, Loss ratio rate, Premium, Life insurance

\begin{abstract}
Abstrak
Dunia perasuransian tidak terlepas dari namanya premi. Setiap produk asuransi yang dijual oleh perusahaan asuransi pasti memiliki harga premi yang selalu mengikutinya. Perusahaan asuransi harus memastikan apakah premi yang telah ditetapkan sebelumnya atas suatu produk masih bisa digunakan pada penjualan selanjutnya dalam rangka memenuhi kewajiban atas klaim yang diajukan oleh nasabah. Untuk menetapkan premi yang tepat bagi konsumen, perusahaan asuransi dapat melakukan experience study yang didasarkan pada informasi masa lalu. Dalam penelitian ini experience study diaplikasikan dalam risiko klaim produk asuransi jiwa $X$ yang dijual oleh perusahaan asuransi jiwa $Y$. Dengan menggunakan experience study akan dihasilkan claim loss ratio rate untuk mengetahui bagaimana perbandingan keadaan aktual klaim terhadap risiko yang diharapkan oleh perusahaan asruansi dalam bentuk premi sehingga dapat membantu perusahaan asuransi dalam pengambilan keputusan perubahan harga premi. Hasil akhir penelitian ini menghasilkan kesimpulan bahwa claim loss ratio rate untuk produk $\mathrm{X}$ baik untuk nasabah laki-laki dan perempuan berada di bawah $100 \%$ dan di bawah batas umum (40-50\%) sehingga premi yang ditetapkan masih mencukupi untuk
\end{abstract}


membayar klaim yang diajukan dan perusahaan asuransi dapat mempertimbangkan penurunan harga premi produk $\mathrm{X}$.

Kata kunci: Experience study, Loss ratio rate, Premi, Asuransi Jiwa

\section{Pendahuluan}

Asuransi merupakan perjanjian antara dua pihak, yaitu perusahaan asuransi dan pemegang polis yang menjadi dasar bagi penerimaan premi oleh perusahaan asuransi sebagai imbalan untuk memberikan penggantian atas kerugian finansial yang dialami oleh tertanggung atau pemegang polis. Dana asuransi merupakan kumpulan dana yang berasal dari premi yang dibentuk untuk memenuhi kewajiban yang timbul dari polis yang diterbitkan atau klaim asuransi (Nasution \& Nanda, 2017).

Berdasarkan Dictionary of Health Insurance and Managed Care, premi merupakan sejumlah uang yang dibebankan oleh perusahaan asuransi kepada tertanggung untuk pertanggungan asuransi.

Perusahaan asuransi adalah salah satu perusahaan bisnis di Indonesia yang memiliki dan menghasilkan data yang berukuran besar tiap bulannya. Jika perusahaan asuransi masih menggunakan data manual seperti file excel dan query pada database, banyaknya data akan membuat proses pengambilan informasi berjalan lamban (Hasim, 2019).

Perusahaan asuransi harus memastikan apakah premi yang telah ditetapkan sebelumnya atas suatu produk masih bisa digunakan pada penjualan selanjutnya dalam rangka memenuhi kewajiban atas klaim yang diajukan oleh nasabah. Untuk menetapkan premi yang tepat bagi konsumen, perusahaan asuransi dapat melakukan experience study yang didasarkan pada informasi masa lalu.

Asuransi sudah menjadi pilihan untuk masa depan nantinya. Karena asuransi adalah solusi bagi orang-orang yang mampu membuat rencana kedepan yang panjang dan matang. Selain itu di negara-negara maju pun asuransi sudah menjadi solusi untuk masa depan nantinya. Oleh sebab itu masyarakat Indonesia diharuskan menggunakan asuransi agar nantinya aman dalam melakukan rutinitas sehari-hari (Sanubari, Yuli, \& Kinasih, 2020).

Menurut Margaretha et al (2019), experience study merupakan salah satu instrumen yang digunakan untuk mengukur pengalaman aktual terhadap risiko yang diharapkan dan untuk memeriksa kecukupan tingkat premi. Experience study juga dapat bertindak sebagai sistem peringatan untuk menyoroti segmen yang telah diberi harga tidak sesuai baik terlalu tinggi atau terlalu rendah dan dengan demikian akan membantu perusahaan dalam menentukan harga premi. Dengan mengevaluasi pengalaman masa lalu, perusahaan dapat membuat keputusan dalam pengembangan produk masa depan dan penjaminan bisnisnya.

Sebuah experience study membandingkan pengalaman aktual dengan model bagaimana perusahaan asuransi mengantisipasi pengalaman tersebut. Menurut Nabholz 
et al (2007), hal ini mengacu pada rasio A/E dimana A sebagai pengalaman aktual dan $\mathrm{E}$ sebagai risiko yang diharapkan.

Salah satu rasio A/E yaitu loss ratio rate. Melalui claim loss ratio rate, perusahaan asuransi dapat melihat perbandingan antara besaran klaim yang diajukan oleh nasabah dengan premi yang telah dibayarkan oleh nasabah. Dengan melihat claim ratio rate perusahaan asuransi dapat mengetahui apakah premi yang telah ditetapkan sebelumnya sesuai dengan yang diperlukan oleh perusahaan asuransi sehingga perusahaan asuransi dapat membuat keputusan atas perubahan premi produk asuransi yang dijualnya agar baik perusahaan asuransi dan juga nasabah tidak mengalami kerugian.

\section{Metode Penelitian}

Metode yang digunakan untuk mencapai tujuan penelitian ini yaitu metode Experience Study dengan fokus pada risiko klaim produk asuransi jiwa individu. Experience study dengan fokus pada risiko klaim produk asuransi jiwa individu akan menghasilkan claim loss ratio rate yang menjadi indikator pengambilan keputusan perubahan premi produk asuransi. Sesuai definisi bahwa claim loss ratio rate merupakan perbandingan antara besaran klaim yang diajukan dengan premi yang telah dibayarkan oleh nasabah maka claim loss ratio rate dapat dirumuskan sebagai berikut:

$$
\text { Claim Loss Ratio Rate }=\frac{\text { Besaran Klaim Aktual }}{\text { Premi }} \times 100 \%
$$

Dimana besaran klaim aktual merupakan rata-rata besar klaim untuk setiap unit exposure dan premi merupakan pure premi (premi tanpa expense dan loading) tahunan untuk setiap paket produk X yang ditetapkan perusahaan asuransi jiwa Y.

Besaran klaim aktual dirumuskan sebagai berikut:

$$
\text { Besaran Klaim Aktual }=\frac{\text { Total Besar Klaim untuk semua nasabah }}{\text { Total exposure semua nasabah }}
$$

Exposure mengacu pada kerentanan individu terhadap berbagai risiko yang dihadapi dalam kehidupan sehari-hari. Ini menunjukkan potensi individu untuk kecelakaan dan kerugian lainnya. Perusahaan asuransi mengevaluasi tingkat risiko yang dihadapi individu dan menggunakannya untuk menghitung premi asuransi. Dalam asuransi jiwa seorang nasabah berpotensi mengalami risiko setiap waktunya, sehingga exposure dalam asuransi jiwa yaitu dalam waktu yang dikonversikan dalam tahun.

Besaran klaim aktual akan dihitung untuk setiap paket dan semua rentang umur berdasarkan jenis kelamin nasabah. Total dari besaran klaim aktual untuk setiap rentang umur di paket yang sama akan menjadi besaran klaim aktual untuk paket tersebut.

Menurut Asosiasi Asuransi Jiwa Indonesia (AAJI), 3 faktor yang menentukan premi yaitu jenis kelamin, usia dan jumlah uang pertanggungan. Perusahaan asuransi jiwa Y juga menetapkan pure premi berdasarkan jenis kelamin rentang usia dan paket produk. Perusahaan asuransi jiwa Y membagi usia dalam 15 rentang yaitu (0-17), (1825), (26-30), (31-35), (36-40), (41-45), (46-50), (51-55), (56-60), (61-65), (66-70), (71- 
75), (76-80), (81-85) dan (86-90) tahun. Untuk jumlah pertanggungan produk, perusahaan asuransi jiwa Y menjual 7 paket produk dimana paket tertinggi (7) merupakan paket dengan jumlah pertanggungan tertinggi.

Claim loss ratio rate akan dihitung untuk semua paket produk $\mathrm{X}$ dan untuk secara keseluruhan produk $\mathrm{X}$ yang dijual oleh perusahaan asuransi jiwa $\mathrm{Y}$ berdasarkan jenis kelamin nasabah. Jika nilai loss ratio rate > 100\% artinya besar premi yang ditetapkan oleh perusahaan asuransi tidak dapat menutupi besar klaim yang diajukan oleh nasabah atau perusahaan asuransi mengalami kerugian dan harus dilakukan proses penaikan premi, sebaliknya jika perusahaan merasa nilai loss ratio rate yang diperoleh masih jauh di bawah batas normal maka perusahaan dapat melakukan penurunan premi. Umumnya claim loss ratio rate untuk sebuah produk berkisar antara $40 \%$ sampai $50 \%$.

Data yang digunakan yaitu data polis dari 23.684 nasabah yang membeli produk asuransi jiwa X dari tahun 2017 hingga 2018, data klaim dari 23.684 nasabah tersebut dari mulai aktif polis hingga tanggal 18 April 2019 (masa akhir studi) dan data premi produk $\mathrm{X}$ untuk semua paket, semua rentang usia, dan jenis kelamin yang diperoleh dari perusahaan asuransi jiwa swasta di Indonesia.

Data polis terdiri dari data nomor polis, nomor nasabah, jenis kelamin, usia, tanggal aktif polis, status polis (aktif/tidak), tanggal akhir polis (kosong untuk polis aktif) dan paket produk (terdiri dari 7 paket produk yang diberi kode 1-7). Data klaim terdiri dari data nomor klaim, nomor polis, nomor nasabah, tanggal klaim, dan besar klaim yang dibayarkan untuk setiap kasus klaim.

Dari data polis dan klaim nasabah kemudian dibuat dataset baru yang berisi nomor polis, nomor nasabah, jenis kelamin, usia, paket produk, banyak klaim (banyaknya kasus klaim dengan nomor polis dan nomor nasabah yang sama), besar klaim (total besar klaim keseluruhan kasus klaim untuk nomor polis dan nomor nasabah yang sama) dan exposure (banyaknya bulan menjadi nasabah dari mulai tanggal polis aktif hingga tanggal akhir polis (untuk polis dengan status tidak aktif) atau hingga tanggal 18 April 2019 (untuk polis dengan status aktif) yang dikonversikan dalam tahun).

\section{Hasil dan Pembahasan}

\section{Claim loss ratio rate Nasabah Laki-laki}

Total besaran klaim semua nasabah laki-laki di rentang usia (0-17) tahun untuk produk $\mathrm{X}$ dengan paket 1 sebesar Rp. 331.158.000. Selengkapnya total besaran klaim semua nasabah laki-laki untuk semua paket produk $\mathrm{X}$ disajikan dalam Tabel 1. Dari Tabel 1. terlihat bahwa nasabah laki-laki di rentang usia 0-17 tahun dominan melakukan klaim dengan besaran yang lebih tinggi dibandingkan rentang usia lain. 
Tabel 1 Total Besaran Klaim Nasabah Laki-laki Produk Asuransi X

\begin{tabular}{crrrrrrr}
\hline Rentang & \multicolumn{7}{c}{ Paket Produk (Juta Rupiah) } \\
\cline { 2 - 9 } Usia & Paket 1 & Paket 2 & Paket 3 & Paket 4 & Paket 5 & Paket 6 & Paket 7 \\
\hline $0-17$ & 331,158 & 713,329 & 288,334 & 848,480 & 0 & 0 & 0 \\
\hline $18-25$ & 53,987 & 136,650 & 137,341 & 475,476 & 0 & 14,345 & 0 \\
\hline $26-30$ & 48,011 & 197,113 & 106,014 & 220,693 & 0 & 32,551 & 0 \\
\hline $31-35$ & 33,528 & 228,803 & 70,592 & 532,310 & 30,413 & 7,112 & 0 \\
\hline $36-40$ & 38,661 & 196,614 & 249,116 & 325,198 & 1,096 & 92,365 & 0 \\
\hline $41-45$ & 7,975 & 126,487 & 76,983 & 257,335 & 0 & 33,181 & 0 \\
\hline $46-50$ & 33,608 & 87,104 & 41,266 & 270,041 & 0 & 233,471 & 0 \\
\hline $51-55$ & 52,957 & 148,051 & 71,684 & 761,450 & 0 & 0 & 0 \\
\hline $56-60$ & 37,158 & 61,325 & 42,869 & 168,026 & 123,057 & 0 & 0 \\
\hline $61-65$ & 38,848 & 83,171 & 6,895 & 204,516 & 0 & 0 & 0 \\
\hline $66-70$ & 22,204 & 23,995 & 18,709 & 0 & 0 & 0 & 0 \\
\hline $71-75$ & 0 & 0 & 0 & 0 & 0 & 0 & 0 \\
\hline $76-80$ & 0 & 0 & 0 & 0 & 0 & 0 & 0 \\
\hline $81-85$ & 0 & 0 & 0 & 0 & 0 & 0 & 0 \\
\hline $86-90$ & 0 & 0 & 0 & 0 & 0 & 0 & 0 \\
\hline
\end{tabular}

Sumber: data sekunder yang telah diolah

Tabel 2 Total Exposure Klaim Nasabah Laki-laki Produk Asuransi X

\begin{tabular}{lrrrrrrr}
\hline Rentang & \multicolumn{7}{c}{ Paket Produk } \\
\cline { 2 - 8 } Usia & Paket 1 & \multicolumn{1}{c}{ Paket 2 } & Paket 3 & Paket 4 & Paket 5 & Paket 6 & Paket 7 \\
\hline $0-17$ & 1670.08 & 1593.75 & 557.25 & 903.25 & 2.83 & 5.00 & 1.50 \\
\hline $18-25$ & 409.92 & 434.92 & 157.58 & 292.58 & 20.67 & 5.67 & 0 \\
\hline $26-30$ & 332.58 & 451.75 & 162.83 & 253.58 & 18.33 & 12.67 & 0.92 \\
\hline $31-35$ & 437.00 & 534.83 & 233.58 & 376.42 & 30.83 & 20.17 & 1.00 \\
\hline $36-40$ & 493.92 & 518.25 & 236.17 & 349.92 & 41.25 & 29.50 & 1.75 \\
\hline $41-45$ & 434.00 & 419.17 & 189.33 & 322.08 & 24.33 & 17.67 & 2.75 \\
\hline $46-50$ & 335.92 & 276.08 & 126.42 & 248.17 & 29.67 & 28.25 & 3.00 \\
\hline $51-55$ & 196.92 & 175.42 & 118.33 & 198.92 & 21.00 & 12.75 & 0.92 \\
\hline $56-60$ & 116.00 & 102.83 & 95.83 & 131.67 & 7.75 & 5.17 & 4.17 \\
\hline $61-65$ & 51.08 & 83.92 & 58.08 & 64.00 & 0.00 & 1.58 & 0.75 \\
\hline $66-70$ & 19.58 & 31.08 & 30.25 & 22.58 & 1.67 & 0.67 & 1.67 \\
\hline $71-75$ & 0.83 & 0.75 & 0 & 0 & 0 & 0 & 0 \\
\hline $76-80$ & 0 & 0 & 0 & 0 & 0 & 0 & 0 \\
\hline $81-85$ & 0 & 0 & 0 & 0 & 0 & 0 & 0 \\
\hline $86-90$ & 0 & 0 & 0 & 0 & 0 & 0 & 0 \\
\hline Sumberyyyyyy
\end{tabular}

Sumber: data sekunder yang telah diolah

Total exposure semua nasabah laki-laki di rentang usia (0-17) tahun untuk produk X dengan paket 1 sebesar 1.670,08. Selengkapnya total exposure semua nasabah laki-laki untuk semua paket produk X disajikan dalam Tabel 2. 
Dari Tabel 2 terlihat bahwa total exposure untuk nasabah laki-laki berusia 0-17 tahun dominan lebih tinggi dibandingkan rentang usia lainnya. Hal ini manandakan bahwa jumlah nasabah laki-laki berusia 0-17 tahun dominan lebih banyak dibandingkan rentang usia lainnya sehingga menjawab juga fenomena besar klaim nasabah laki-laki di rentang usia 0-17 tahun yang tinggi dikarenakan banyaknya nasabah laki-laki yang klaim lebih banyak dibandingkan rentang usia lainnya.

Tabel 3 Besaran Klaim Aktual Nasabah Laki-laki Produk Asuransi X

\begin{tabular}{|c|c|c|c|c|c|c|c|}
\hline \multirow{2}{*}{$\begin{array}{l}\text { Rentang } \\
\text { Usia }\end{array}$} & \multicolumn{7}{|c|}{ Paket Produk (Juta Rupiah) } \\
\hline & Paket 1 & Paket 2 & Paket 3 & Paket 4 & Paket 5 & Paket 6 & Paket 7 \\
\hline $0-17$ & 0,198 & 0,448 & 0,517 & 0,939 & 0 & 0 & 0 \\
\hline $18-25$ & 0,132 & 0,314 & 0,872 & 1,625 & 0 & 2,532 & - \\
\hline $26-30$ & 0,144 & 0,436 & 0,651 & 0,870 & 0 & 2,570 & 0 \\
\hline $31-35$ & 0,077 & 0,428 & 0,302 & 1,414 & 0,986 & 0,353 & 0 \\
\hline $36-40$ & 0,078 & 0,379 & 1,055 & 0,929 & 0,027 & 3,131 & 0 \\
\hline $41-45$ & 0,018 & 0,302 & 0,407 & 0,799 & 0 & 1,878 & 0 \\
\hline $46-50$ & 0,100 & 0,315 & 0,326 & 1,088 & 0 & 8,264 & 0 \\
\hline $51-55$ & 0,269 & 0,844 & 0,606 & 3,828 & 0 & 0 & 0 \\
\hline $56-60$ & 0,320 & 0,596 & 0,447 & 1,276 & 15,878 & 0 & 0 \\
\hline $61-65$ & 0,760 & 0,991 & 0,119 & 3,196 & - & 0 & 0 \\
\hline 66-70 & 1,134 & 0,772 & 0,618 & 0 & 0 & 0 & 0 \\
\hline $71-75$ & 0 & 0 & - & - & - & - & - \\
\hline $76-80$ & - & - & - & - & - & - & - \\
\hline $81-85$ & - & - & - & - & - & - & - \\
\hline $86-90$ & - & - & - & - & - & - & - \\
\hline $\begin{array}{l}\text { Total/Pake } \\
\mathrm{t}\end{array}$ & 3,231 & 5,826 & 5,920 & 15,965 & 16,891 & 18,728 & 0 \\
\hline
\end{tabular}

Sumber: data sekunder yang telah diolah

Ket: “_“ artinya tidak terdapat nasabah laki-laki dengan kriteria usia dan paket tersebut dan " 0 " artinya tidak terdapat klaim yang diajukan oleh nasabah laki-laki dengan kriteria usia dan paket tersebut.

Besaran klaim aktual untuk nasabah laki-laki yang membeli produk $\mathrm{X}$ dengan paket 1 direntang usia 0-17 tahun sebesar Rp. 198.000 diperoleh dari

$$
\text { Besaran Klaim Aktual }=\frac{R p \cdot 331.158 .000}{1.670,08}=R p .198 .000
$$

Besaran klaim aktual untuk nasabah laki-laki yang membeli produk $\mathrm{X}$ dengan paket 1 sebesar Rp. 3.231.000, diperoleh dari total besaran klaim aktual dari nasabah laki-laki yang membeli produk $X$ dengan paket 1 dari rentang usia 0-17 tahun hingga 86-90 tahun. Besaran klaim aktual sebesar Rp. 3.231.000 memiliki arti bahwa nasabah laki-laki yang membeli produk $\mathrm{X}$ dengan paket 1 rata-rata mengajukan klaim sebesar Rp.3.231.000 setiap tahunnya. Selengkapnya besaran 
klaim aktual nasabah laki-laki untuk semua paket produk $\mathrm{X}$ disajikan dalam Tabel 3. Dari Tabel 3. terlihat bahwa jumlah uang pertanggungan mempengaruhi besar klaim aktual dimana semakin tinggi paket semakin tinggi pula besar aktual klaim yang terjadi.

Tabel 4 Pure Premi Nasabah Laki-laki Produk Asuransi X

\begin{tabular}{lrrrrrrr}
\hline Rentang Usia & \multicolumn{7}{c}{ Paket Produk (Juta Rupiah) } \\
\cline { 2 - 8 } & Paket 1 & Paket 2 & Paket 3 & Paket 4 & Paket 5 & Paket 6 & Paket 7 \\
\hline $0-17$ & 0,924 & 1,465 & 2,060 & 3,137 & 4,531 & 5,317 & 6,605 \\
\hline $18-25$ & 1,202 & 1,907 & 2,687 & 4,083 & 5,911 & 6,940 & - \\
\hline $26-30$ & 0,909 & 1,465 & 2,067 & 3,137 & 4,546 & 5,339 & 6,632 \\
\hline $31-35$ & 0,972 & 1,581 & 2,241 & 3,386 & 4,913 & 5,773 & 7,174 \\
\hline $36-40$ & 1,026 & 1,698 & 2,414 & 3,635 & 5,281 & 6,208 & 7,719 \\
\hline $41-45$ & 1,088 & 1,791 & 2,577 & 3,834 & 5,579 & 6,559 & 8,158 \\
\hline $46-50$ & 1,135 & 1,907 & 2,762 & 4,083 & 5,951 & 7,001 & 8,710 \\
\hline $51-55$ & 1,179 & 2,023 & 2,952 & 4,332 & 6,326 & 7,445 & 9,265 \\
\hline $56-60$ & 1,400 & 2,441 & 3,582 & 5,228 & 7,651 & 9,009 & 11,220 \\
\hline $61-65$ & 1,691 & 2,930 & 4,299 & 6,274 & - & 10,811 & 13,472 \\
\hline $66-70$ & 2,125 & 3,663 & 5,374 & 7,843 & 11,477 & 13,514 & 16,852 \\
\hline $71-75$ & 2,777 & 4,762 & - & - & - & - & - \\
\hline $76-80$ & - & - & - & - & - & - & - \\
\hline $81-85$ & - & - & - & - & - & - & - \\
\hline $86-90$ & - & - & - & - & - & - & - \\
\hline Total/Paket & 16,428 & 27,633 & 33,014 & 48,973 & 62,165 & 83,914 & 95,808 \\
\hline Total & & & & & & & 367,935 \\
\hline Shyyyyyyy
\end{tabular}

Sumber: data sekunder yang telah diolah

Ket: “_“ artinya tidak terdapat nasabah dengan kriteria usia dan paket tersebut.

Premi nasabah laki-laki yang membeli produk X dengan paket 1 sebesar Rp. 16.428.000 diperoleh dari total pure premi tahunan nasabah laki-laki untuk semua rentang usia yang berkontribusi di produk $\mathrm{X}$ dengan paket 1 yaitu dari rentang usia 0-17 tahun hingga 71-75 tahun. Selengkapnya premi nasabah laki-laki untuk semua paket produk X disajikan dalam Tabel 4. Dari Tabel 4. terlihat bahwa jumlah uang pertanggungan mempengaruhi pure premi yang ditetapkan dimana semakin tinggi paket semakin tinggi pula pure premi yang ditetapkan.

Claim loss ratio rate untuk nasabah laki-laki yang membeli produk $\mathrm{X}$ dengan paket 1 sebesar $19,670 \%$ diperoleh dari

$$
\text { Claim Loss Ratio Rate }=\frac{R p \cdot 3 \cdot 231.000}{R p \cdot 16.428 .000} \times 100 \%=19,67 \%
$$

Yang artinya rata-rata perusahaan asuransi jiwa Y menggunakan 19,67\% premi yang dibayarkan oleh nasabah laki-laki yang membeli produk $\mathrm{X}$ dengan paket 1 untuk membayar klaim yang diajukan oleh nasabah laki-laki yang membeli 
produk $\mathrm{X}$ dengan paket 1 . Selengkapnya claim loss ratio rate nasabah laki-laki untuk semua paket produk X disajikan dalam Tabel 5.

Tabel 5 Claim loss ratio rate Nasabah Laki-laki Produk Asuransi X

\begin{tabular}{|c|c|c|c|c|c|c|c|}
\hline \multirow{3}{*}{$\begin{array}{l}\text { Claim } \\
\text { loss ratio } \\
\text { rate }(\%)\end{array}$} & \multicolumn{7}{|c|}{ Paket Produk } \\
\hline & Paket 1 & Paket 2 & Paket 3 & Paket 4 & Paket 5 & Paket 6 & Paket 7 \\
\hline & 19,670 & 21,083 & 17,933 & 32,600 & 27,172 & 22,318 & 0 \\
\hline Total & & & & & & & 18,091 \\
\hline
\end{tabular}

Sumber: data sekunder yang telah diolah

Jika dilihat berdasarkan paket produk $\mathrm{X}$, claim loss ratio rate nasabah lakilaki masih jauh dibawah $100 \%$ yang artinya premi yang terkumpul masih sangat mencukupi untuk membayar klaim yang diajukan oleh nasabah. Secara keseluruhan produk X, claim loss ratio rate untuk nasabah laki-laki sebesar 18,091\% yang artinya $18,091 \%$ dari premi yang dibayarkan oleh nasabah laki-laki digunakan untuk membayar klaim yang diajukan.

Claim loss ratio rate untuk nasabah laki-laki yang membeli produk $\mathrm{X}$ masih jauh dibawah $100 \%$ bahkan masih dibawah batas umumnya (40-50\%) sehingga perusahaan asuransi jiwa dapat mempertimbangkan untuk menurunkan harga premi produk X untuk nasabah laki-laki.

\section{Claim loss ratio rate Nasabah Perempuan}

Dengan cara yang sama dengan perhitungan claim loss ratio rate nasabah laki-laki diperoleh claim loss ratio rate nasabah perempuan yang membeli produk $\mathrm{X}$ yang disajikan dalam Tabel 6 .

Pada Tabel 6. jika dilihat berdasarkan paket produk X, claim loss ratio rate nasabah perempuan masih jauh dibawah $100 \%$ yang artinya premi yang terkumpul masih sangat mencukupi untuk membayar klaim yang diajukan oleh nasabah. Secara keseluruhan produk $\mathrm{X}$, claim loss ratio rate untuk nasabah perempuan sebesar 20,385\% yang artinya 20,385\% dari premi yang dibayarkan oleh nasabah perempuan digunakan untuk membayar klaim yang diajukan.

\section{Tabel 6 Claim loss ratio rate Nasabah Perempuan Produk Asuransi X}

\begin{tabular}{|c|c|c|c|c|c|c|c|}
\hline \multirow{3}{*}{$\begin{array}{l}\text { Claim } \\
\text { loss ratio } \\
\text { rate }(\%)\end{array}$} & \multicolumn{7}{|c|}{ Paket Produk } \\
\hline & Paket 1 & Paket 2 & Paket 3 & Paket 4 & Paket 5 & Paket 6 & Paket 7 \\
\hline & 11,383 & 23,592 & 25,028 & 26,613 & 17,962 & 34,664 & 0 \\
\hline Total & & & & & & & 20,385 \\
\hline
\end{tabular}

Sumber: data sekunder yang telah diolah

Claim loss ratio rate untuk nasabah perempuan yang membeli produk $\mathrm{X}$ masih jauh dibawah $100 \%$ bahkan masih dibawah batas umumnya (40-50\%) sehingga perusahaan asuransi jiwa dapat mempertimbangkan untuk menurunkan harga premi produk $\mathrm{X}$ untuk nasabah perempuan. 


\section{Kesimpulan}

Claim loss ratio rate untuk produk $\mathrm{X}$ yang dijual oleh perusahaan asuransi jiwa $\mathrm{Y}$ baik untuk nasabah laki-laki dan perempuan berada dibawah $100 \%$ yang artinya premi yang ditetapkan masih mecukupi untuk membayar klaim yang diajukan oleh nasabah. Dikarenakan claim loss ratio rate masih dibawah $100 \%$ maka perusahaan asuransi jiwa $\mathrm{Y}$ tidak perlu menaikkan premi, namun dikarenakan baik claim loss ratio rate nasabah laki-laki maupun permpuan berada dibawah batas normal (40-50\%) maka perusahaan asuransi jiwa $\mathrm{Y}$ dapat mempertimbangkan penuruan premi. Penurunan harga premi dapat meningkatkan daya jual produk dikemudian hari dan juga dapat meningkatkan tingkat kepuasaan nasabah atas produk yang telah dibelinya. Dengan melihat claim loss ratio rate perusahaan asuransi dapat mengetahui perbandingan besar klaim dengan premi yang dibayarkan oleh nasabah sehingga perusahaan asuransi dapat menjadikan claim loss ratio rate sebagai acuan dalam mengambil keputusan perubahan harga premi produk asuransi. 
Mardianto Karim dan Aceng Komarudin Mutaqin

\section{BIBLIOGRAFI}

Atkinson, David B. \& Mcgarry, John K. (2016). Experience Study Calculations. United States: Society of Actuaries.

Hasim, L. (2019). Penerapan Business Intelligence Pada Manajemen Dashboard Report Perusahaan Asuransi. Syntax Literate; Jurnal Ilmiah Indonesia, 4(12), 123-136.

Marcinko, David Edward. (2006). Dictionary of Health Insurance and Managed Care. New York: Springer Publishing Company.

Margaretha, H., Susanto, M., Lionel, E. O., \& Ferdinand, F. V. (2019). An actuarial model of stroke long term care insurance with obesity as a risk factor. AIP Conference Proceedings, 2192(1), 30004. AIP Publishing LLC.

Nabholz, C., Caroll, J. L., Wekwete, C., \& Sommerville, K. (2007). Life Risk Selection at a Fair Price: Reinforcing the Actuarial Basis. Zurich: Swiss Re.

Nasution, N. H., \& Nanda, S. T. (2017). Pengaruh Pendapatan Premi, Hasil Underwriting, Hasil Investasi Dan Risk Based Capital Terhadap Laba Perusahaan Asuransi Umum Syariah.

Sanubari, L., Yuli, S., \& Kinasih, H. (2020). Bahasa Indonesia. Syntax Idea, 2(1), 4858. 